\title{
Evaluation of the capacity of oral streptococci to produce hydrogen peroxide
}

\author{
A. GARCÍA-MENDOZA, J. LIÉBANA*, ANA M. CASTILLO, ANGUSTIAS DE LA HIGUERA \\ and G. PIÉDROLA
}

Department of Microbiology, School of Medicine and *School of Odontology, University of Granada, Avda. de Madrid n.11. E-18071 Granada, Spain

\begin{abstract}
Summary. The capacity of 11 strains of oral streptococcal species (Streptococcus sanguis, $S$. oralis, S. mitis and S. sobrinus) to produce hydrogen peroxide $\left(\mathrm{H}_{2} \mathrm{O}_{2}\right)$ was studied in vitro. Detection of this property in solid media, particularly with trypticase soy agar-benzidineperoxidase, was more sensitive than in liquid media. The addition of carbohydrates (arabinose, xylose, mannose, sorbose and lactose), sorbitol and saccharine to buffered trypticase soy broth increased $\mathrm{H}_{2} \mathrm{O}_{2}$ production in $S$. oralis NCTC 11427, although the concentrations obtained with some substrates (glucose, galactose, mannitol and xylitol) were lower than those obtained in controls. In $S$. sanguis NCTC $7863, \mathrm{H}_{2} \mathrm{O}_{2}$ production was detected only with galactose, sorbitol, lactose and saccharin.
\end{abstract}

\section{Introduction}

Some members of the genus Streptococcus are able to produce substances, such as $\mathrm{H}_{2} \mathrm{O}_{2}$, that inhibit the growth of other micro-organisms. ${ }^{1-4}$ McLeod and Gordon ${ }^{5}$ were the first to study its production by $S$. pneumoniae. Thompson and Johnson ${ }^{6}$ reported that the inhibitory properties of saliva were due to $\mathrm{H}_{2} \mathrm{O}_{2}$ produced by oral streptococci and Hamon and Klebanoff $^{7}$, Holmberg and Hallander ${ }^{1}$, LeBien and Bromel $^{2}$ and Willcox and Drucker ${ }^{4}$ also investigated the inhibitory capacity of $\mathrm{H}_{2} \mathrm{O}_{2}$ produced by various strains of oral streptococci. Other studies have investigated the relationship between the capacity of oral streptococci to produce $\mathrm{H}_{2} \mathrm{O}_{2}$ in relation to available substrates such as glucose..$^{8-10}$

The metabolism of facultatively anaerobic streptococci is anaerobic, depending mainly on glycolysis to generate adenosine triphosphate (ATP), and producing lactic acid as the main end-product. ${ }^{11}$ Because these streptococci are unable to form haemic groups, they cannot synthesise most of the enzymes required for oxygen metabolism (cytochromes) or catalase. ${ }^{12,13}$ Moreover, these micro-organisms can take up oxygen in amounts similar to those used by aerobic bacteria, due to their flavoproteins such as NADH-oxidase, ${ }^{12}$ which are able to reduce oxygen by one, two or four electrons to superoxide anion $\left(\mathrm{O}_{2}^{-}\right), \mathrm{H}_{2} \mathrm{O}_{2}$ or water, respectively. Superoxide anion and $\mathrm{H}_{2} \mathrm{O}_{2}$ are highly toxic to the micro-organisms, and are removed from the medium by superoxide dismutase (SOD) $)^{8,14}$ and NADH-peroxidase ${ }^{15}$ respectively.
This qualitative and quantitative study of $\mathrm{H}_{2} \mathrm{O}_{2}$ production by 11 strains of oral streptococci was designed to investigate the influence of 11 carbohydrates, three polyalcohols and saccharin on $\mathrm{H}_{2} \mathrm{O}_{2}$ production.

\section{Materials and methods}

\section{Micro-organisms}

S. oralis NCTC 11427 , S. mitis NCTC 3165 , and $S$. sanguis JENA 2697 and NCTC 7863 were obtained from international collections, and $S$. mitis strains OGS $218,232,420$ and 628 and $S$. sobrinus strains OGS, 415, 324 and 529 were from the Microbiology Laboratory collection of the University of Granada Hospital (OGS = Odontología Granada Streptococcus). These strains were identified according to the criteria described by Hardie ${ }^{16}$ and Loesche. ${ }^{17}$

\section{Qualitative study of $\mathrm{H}_{2} \mathrm{O}_{2}$ production}

Qualitative studies of $\mathrm{H}_{2} \mathrm{O}_{2}$ production were performed with two media--trypticase soy agar-orthodianisidine (TSA-o-D) and TSA-benzidine-peroxidase (TSA-B-P).

TSA-o-D was prepared by adding to $1 \mathrm{~L}$ of TSA (Difco) $10 \mathrm{ml} / \mathrm{L}$ of a solution of $o$-dianisidine (Sigma; $5 \mathrm{mg} / \mathrm{ml}$ in methanol) at $45^{\circ} \mathrm{C}$. The medium was prepared with double-distilled water and was sterilised by autoclaving.

TSA-B-P was prepared by adding $10 \mathrm{ml}$ of benzidine $5 \mathrm{mg} / \mathrm{ml}$ (Sigma) to $1 \mathrm{~L}$ of TSA and horseradish 


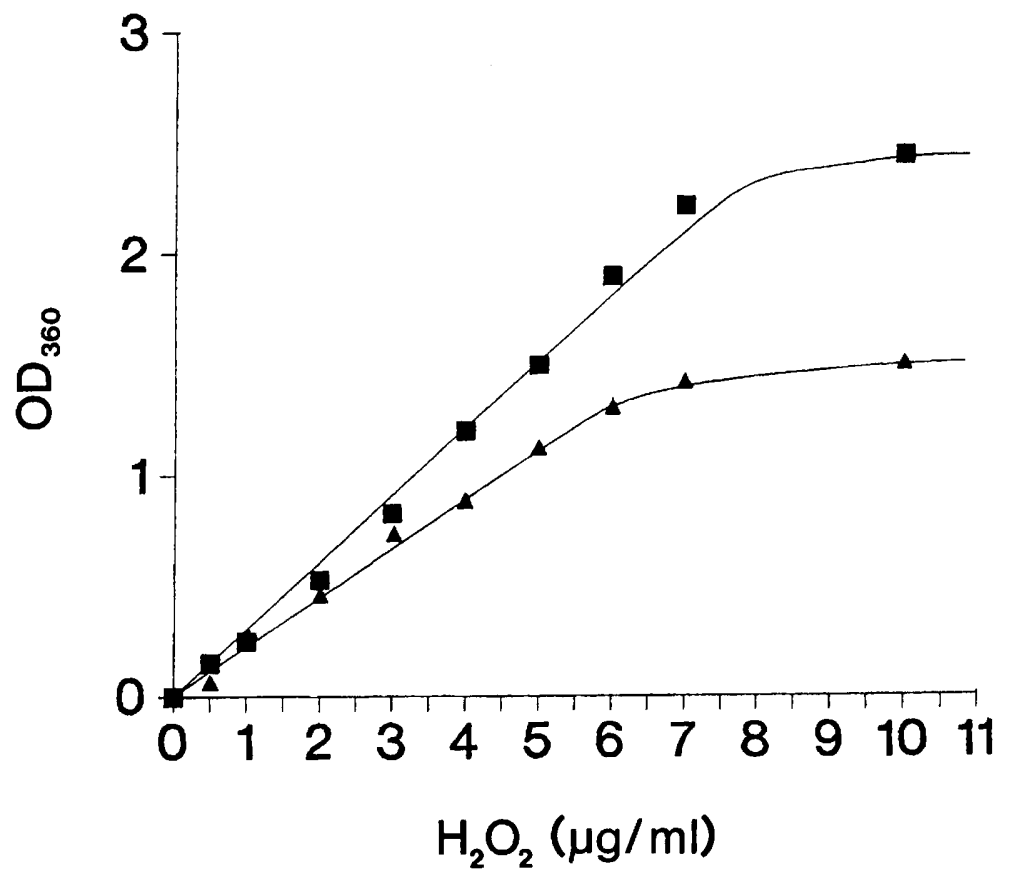

Fig. 1. Standard curve for $\mathbf{H}_{2} \mathrm{O}_{2}$ production in B-TSB $\left(-\boldsymbol{\Delta}^{-}\right)$and B-TSB plus substrate $\left(-\boldsymbol{\square}_{-}\right)$.

peroxidase (EC 1.11.1.7; Sigma) solution (HRP) to a final concentration $1 \mathrm{mg} / \mathrm{ml}$, at $45^{\circ} \mathrm{C}$.

The 11 strains were inoculated on to plates of TSA$O-D$ and TSA-B-P and incubated under anaerobic conditions at $36^{\circ} \mathrm{C} \pm 1^{\circ}$ for $24 \mathrm{~h}$. For the TSA-o-D medium, a second incubation for $4 \mathrm{~h}$ at $36^{\circ} \mathrm{C} \pm 1^{\circ}$ aerobically was used, after which the areas of growth were covered with $5 \mu$ lof HRP and left until a colour change to orange (a positive result) was observed (table I). For the TSA-B-P medium, the plates were exposed to atmospheric oxygen at room temperature after anaerobic incubation, and the appearance a few minutes later of a dark brown colour (a positive result) in the growth zone was noted (table I).

\section{Quantitative study of $\mathrm{H}_{2} \mathrm{O}_{2}$ production}

Standard curve. Buffered trypticase soy broth (BTSB) containing (/L) tryptone (Difco) $17 \mathrm{~g}$, soytone (Difco) $3 \mathrm{~g}, \mathrm{PO}_{4} \mathrm{HNa}_{2}$ (Merck, Darmstadt, Germany) $9 \mathrm{~g}$ and $\mathrm{PO}_{4} \mathrm{H}_{2} \mathrm{Na} .2 \mathrm{H}_{2} \mathrm{O}$ (Merck) $5.9 \mathrm{~g}(\mathrm{pH} \mathrm{7.0)}$ was prepared for standard curve assays. The medium was sterilised by the autoclaving.

Solutions $(30 \% \mathrm{w} / \mathrm{v})$ in distilled water of ribose (Sigma), arabinose (Sigma), xylose (Sigma), glucose (Panreac, Barcelona, Spain), mannose (Sigma), galactose (Sigma), fructose (Panreac), sorbose (Sigma), mannitol (Sigma), sorbitol (Sigma), xylitol (Sigma), saccharose (Merck), lactose (Merck), maltose (Panreac) and saccharin (Sigma) were prepared and autoclaved.

Substrate solutions were added to B-TSB to bring the final concentration to $55.5 \mathrm{~mm}$. In addition to individual assays of all substrates, a combination of glucose-galactose solutions $(27.7 \mathrm{~mm}$ each) was also tested.
Commercial $\mathrm{H}_{2} \mathrm{O}_{2}$ (Panreac) $30 \% \mathrm{w} / \mathrm{v}$, was titrated with potassium permanganate. ${ }^{18}$ Dilutions in B-TSB alone and $\mathrm{B}$-TSB with the respective substrate were made with $\mathrm{H}_{2} \mathrm{O}_{2}$ at concentrations of $10,7,6,5,4,3,2$, 1 and $0.5 \mu \mathrm{g} / \mathrm{ml}$. To $3-\mathrm{ml}$ volumes of these dilutions were added $30 \mu$ l benzidine solution $(5 \mathrm{mg} / \mathrm{ml})$ and $30 \mu \mathrm{l}$ of HRP. The mixtures were incubated for $10 \mathrm{~min}$ at $36^{\circ} \mathrm{C} \pm 1^{\circ}$ and the optical density (OD) was measured spectrophotometrically at $360 \mathrm{~nm}$. Controls consisted of $3 \mathrm{ml}$ of B-TSB alone or B-TSB with respective substrate to which were added $30 \mu \mathrm{l}$ of benzidine solution and $30 \mu \mathrm{l}$ of HRP. On the basis of these results, the molar extinction coefficient $(E)$ was calculated..$^{19,20}$ This coefficient relates OD at a given wavelength and concentration, and in this case coincided with the slope of the resulting standard curve (fig. 1). The slope was calculated by the least squares linear regression method. ${ }^{21}$ Pearson's correlation coefficient ( $r),{ }^{21}$ indicating the correlation between the $\mathrm{OD}_{360}$ data and $\left[\mathrm{H}_{2} \mathrm{O}_{2}\right]$, was also calculated. The following data were obtained: B-TSB, $E(\mathrm{ml} / \mu \mathrm{g} / \mathrm{cm})$ $=2.15 \pm 0.016$ and $\mathrm{r}=0.97 \pm 0.03 ; \mathrm{B}-\mathrm{TSB}+$ substrate $(55.5 \mathrm{~mm}), \quad E(\mathrm{ml} / \mu \mathrm{g} / \mathrm{cm})=0.291 \pm 0.019$ and $\mathbf{r}=0.94 \pm 0.03$.

Preliminary experiment. Tubes containing $5 \mathrm{ml}$ of BTSB, which had been deoxygenated by boiling, were inoculated with $0.2 \mathrm{ml}$ of bacterial suspension in saline solution $(\mathrm{NaCl} 0.9 \%$ in double-distilled water, turbidity 0.5 on the McFarland scale) and incubated at $36^{\circ} \mathrm{C} \pm 1^{\circ}$ in anaerobic conditions for $24 \mathrm{~h}$. The cultures were then aerated by shaking (Pfizer Autobac 1, Incubator/Shaker $102 \mathrm{U}$ ) at $37^{\circ} \mathrm{C}$ for $3 \mathrm{~h}$. To each tube were added $50 \mu \mathrm{l}$ of benzidine solution $5 \mathrm{mg} / \mathrm{ml}$ and $50 \mu \mathrm{l}$ of HRP, and the tubes were centrifuged at $8000 \mathrm{~g}$ for $10 \mathrm{~min}$ at $4^{\circ} \mathrm{C}$. The $\mathrm{OD}_{360}$ of the supernate was measured when the $\mathrm{OD}_{360}$ was $>0 \cdot 010$ (table I). 
Table I. Qualitative study of $\mathrm{H}_{2} \mathrm{O}_{2}$ production in TSA-o-D and TSA-B-P, and preliminary quantitative study in B-TSB

\begin{tabular}{|c|c|c|c|c|c|c|c|c|c|c|c|}
\hline \multirow{2}{*}{ Medium } & \multicolumn{11}{|c|}{$\mathrm{H}_{2} \mathrm{O}_{2}$ production by strain no. } \\
\hline & 1 & 2 & 3 & 4 & 5 & 6 & 7 & 8 & 9 & 10 & 11 \\
\hline TSA-o-D & $+\downarrow$ & $+\downarrow$ & $+\downarrow$ & $+\downarrow$ & $+\downarrow$ & $+\downarrow$ & $+\downarrow$ & $+\downarrow$ & $+\downarrow$ & $+\downarrow$ & $+\downarrow$ \\
\hline TSA-B-P & + & + & + & + & + & + & $+\downarrow$ & $+\downarrow$ & + & $+\downarrow$ & + \\
\hline B-TSB & + & - & - & + & - & - & - & - & - & - & - \\
\hline
\end{tabular}

Table II. Maximum concentration, aeration time until maximum production, and rates of excretion of $\mathrm{H}_{2} \mathrm{O}_{2}$ by $S$. oralis NCTC 11427 and S. sanguis NCTC 7863 in B-TSB alone or in combination with the substrate(s)

\begin{tabular}{|c|c|c|c|c|c|c|}
\hline \multirow[b]{2}{*}{ Medium } & \multicolumn{3}{|c|}{$\begin{array}{c}\text { S. oralis } \\
\text { NCTC } 11427\end{array}$} & \multicolumn{3}{|c|}{$\begin{array}{c}\text { S. sanguis } \\
\text { NCTC } 7863\end{array}$} \\
\hline & $\begin{array}{c}{\left[\mathrm{H}_{2} \mathrm{O}_{2}\right] \text { at }} \\
\text { maximum } \\
\text { growth } \\
\left(\mu \mathrm{g} / 10^{6} \mathrm{cfu}\right)\end{array}$ & $\begin{array}{l}\text { Aeration } \\
\text { time }(\mathrm{h}) \text { from } \\
\text { maximum } \\
\text { growth }\end{array}$ & $\begin{array}{c}\text { Rate of } \\
\mathrm{H}_{2} \mathrm{O}_{2} \\
\text { excretion } \\
\left(\mathrm{ng} / \mathrm{min} / 10^{6} \mathrm{cfu}\right)\end{array}$ & $\begin{array}{c}{\left[\mathrm{H}_{2} \mathrm{O}_{2}\right] \text { at }} \\
\text { maximum } \\
\text { growth } \\
\left(\mu \mathrm{g} / 10^{6} \mathrm{cfu}\right)\end{array}$ & $\begin{array}{l}\text { Aeration } \\
\text { time (h) from } \\
\text { maximum } \\
\text { growth }\end{array}$ & $\begin{array}{c}\text { Rate of } \\
\mathrm{H}_{2} \mathrm{O}_{2} \\
\text { excretion } \\
\left(\mathrm{ng} / \mathrm{min} / 10^{6} \mathrm{cfu}\right)\end{array}$ \\
\hline B-TSB alone & $1.32(0.13)^{*}$ & 3 & 5.79 & $0.31(0.08)$ & $4 \cdot 5$ & 1.83 \\
\hline Ribose & $\ldots$ & $\ldots$ & $\ldots$ & $\ldots$ & $\ldots$ & $\ldots$ \\
\hline Arabinose & $3.02(0.24)$ & 8 & $5 \cdot 04$ & $\ldots$ & $\ldots$ & $\ldots$ \\
\hline Xylose & $2 \cdot 08(0 \cdot 19)$ & 12 & 3.05 & $\ldots$ & $\ldots$ & $\ldots$ \\
\hline Glucose & $0 \cdot 17(0.05)$ & $4 \cdot 5$ & $0 \cdot 71$ & $\ldots$ & $\ldots$ & $\ldots$ \\
\hline Mannose & $1.74(0 \cdot 17)$ & 8 & 1.46 & $\ldots$ & $\cdots$ & $\ldots$ \\
\hline Galactose & $0.30(0.07)$ & 6 & 1.04 & $0.23(0.06)$ & 6 & 1.05 \\
\hline Fructose & $\ldots$ & $\ldots$ & $\ldots$ & $\ldots$ & $\ldots$ & $\ldots$ \\
\hline Sorbose & $1.96(0.22)$ & 6 & $5 \cdot 30$ & $\ldots$ & $\ldots$ & $\ldots$ \\
\hline Mannitol & $0.68(0 \cdot 11)$ & 6 & 1.06 & $\ldots$ & $\ldots$ & $\ldots$ \\
\hline Sorbitol & $1.79(0.29)$ & 8 & 5.90 & $1 \cdot 19(0 \cdot 15)$ & 3 & $2 \cdot 78$ \\
\hline Xylitol & $0.60(0.06)$ & 6 & 1.02 & $\ldots$ & $\ldots$ & $\ldots$ \\
\hline Saccharose & $\ldots$ & $\ldots$ & $\ldots$ & $\ldots$ & $\ldots$ & $\ldots$ \\
\hline Lactose & $2.00(0.32)$ & 8 & $2 \cdot 24$ & $0.21(0.05)$ & $4 \cdot 5$ & 0.65 \\
\hline Maltose & $\ldots$ & $\ldots$ & $\ldots$ & $\ldots$ & $\ldots$ & $\ldots$ \\
\hline $\begin{array}{c}\text { Glucose + } \\
\text { galactose }\end{array}$ & $0.70(0.13)$ & 8 & $2 \cdot 00$ & $\ldots$ & $\ldots$ & $\ldots$ \\
\hline Saccharin & $2 \cdot 21(0 \cdot 35)$ & $4 \cdot 5$ & $5 \cdot 08$ & $0.37(0.07)$ & 6 & $1 \cdot 33$ \\
\hline
\end{tabular}

All experiments were performed in triplicate.

* ( ), Standard deviation.

$\mathrm{H}_{2} \mathrm{O}_{2}$ production. Erlenmeyer flasks containing $200 \mathrm{ml}$ of B-TSB alone or with one of the substrates, from which oxygen had been eliminated by boiling, were inoculated with $1 \mathrm{ml}$ of bacterial suspension in saline solution. The suspension was prepared from log-phase cultures in B-TSB or B-TSB plus substrate with a turbidity of 0.5 on the McFarland scale. The flasks were incubated anaerobically at $36^{\circ} \mathrm{C} \pm 1^{\circ}$ for $24 \mathrm{~h}$, placed in a water bath at $37^{\circ} \mathrm{C}$ and aerated by shaking in a circular orbital motion at $900 \mathrm{rpm} ; 3-\mathrm{ml}$ samples were removed periodically and replaced with $3 \mathrm{ml}$ of B-TSB or B-TSB with substrate that had been pre-incubated at $37^{\circ} \mathrm{C}$. To each sample were added $30 \mu \mathrm{l}$ of benzidine solution $5 \mathrm{mg} / \mathrm{ml}$ and $30 \mu \mathrm{l}$ of HRP, and the mixture was centrifuged at $8000 \mathrm{~g}$ for $10 \mathrm{~min}$ at $4^{\circ} \mathrm{C}$. The $\mathrm{OD}_{360}$ of the supernate was measured, compared with the control, and the concentration of $\mathrm{H}_{2} \mathrm{O}_{2}$ was calculated as a function of the corresponding molar extinction coefficient $(E)$.
Viable counts. At the same intervals as in the determinations of $\mathrm{H}_{2} \mathrm{O}_{2}$ concentration, viable counts as $\mathrm{cfu} / \mathrm{ml}$ were determined on Mitis Salivarius Agar (Difco). Serial dilutions of $10^{1}-10^{12}$, depending on the period of aeration and the strain, were prepared from $0.2 \mathrm{ml}$ of the culture, and the plates were incubated anaerobically at $36^{\circ} \mathrm{C} \pm 1^{\circ}$ for $48 \mathrm{~h}$.

\section{Results}

In qualitative studies with both (TSA-o-D and TSAB-P (table I), all strains produced $\mathrm{H}_{2} \mathrm{O}_{2}$ when the cultures were exposed to air, as indicated by a colour change; the greater change was produced with TSAB-P.

Previous quantitative studies with B-TSB (table I) detected $\mathrm{H}_{2} \mathrm{O}_{2}$ production only in strains $S$. oralis NCTC 11427 and S. sanguis NCTC 7863. Therefore, 


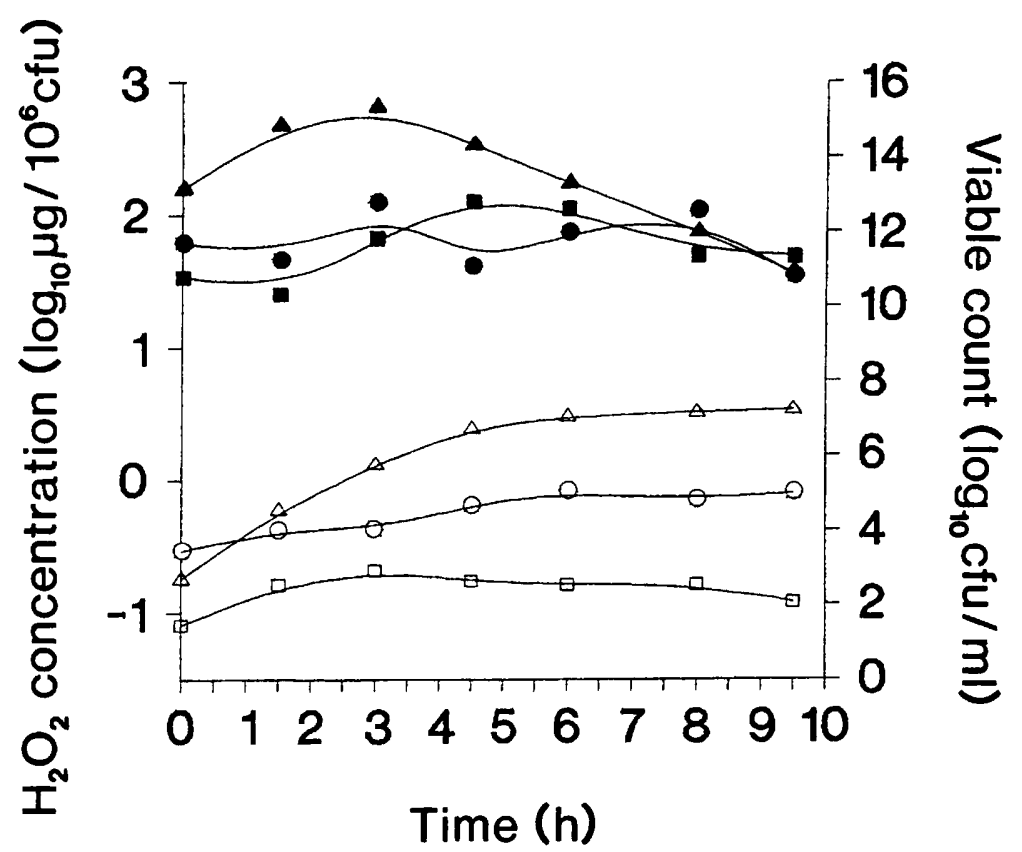

Fig. 2. S. oralis NCTC 11427 in B-TSB alone: growth curve $\left(-\boldsymbol{\Delta}^{-}\right), \mathrm{H}_{2} \mathrm{O}_{2}$ production $\left(-\triangle^{-}\right)$; with glucose: growth curve $\left(-\mathbf{-}^{-}\right), \mathrm{H}_{2} \mathrm{O}_{2}$ production $\left(-\mathrm{O}^{-}\right)$; with glucose plus galactose: growth curve $(--), \mathrm{H}_{2} \mathrm{O}_{2}$ production $\left(-\square^{-}\right)$.

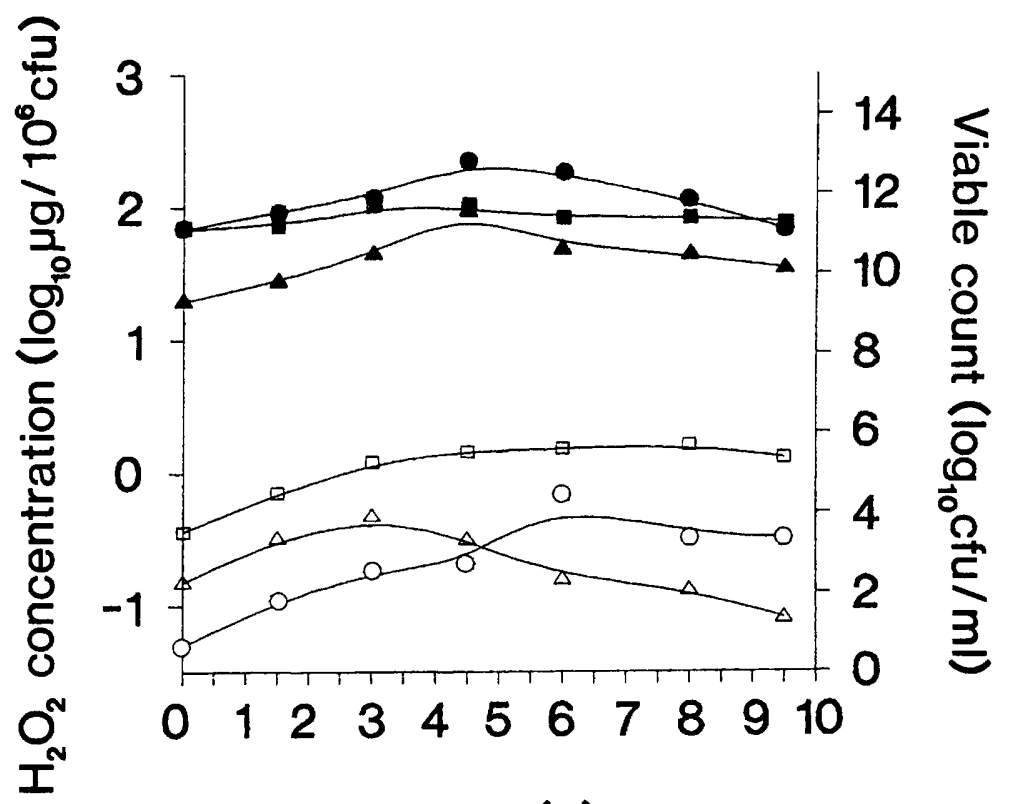

\section{Time (h)}

Fig. 3. S. sanguis NCTC 7863 in B-TSB alone: growth curve $(-\Delta-), \mathrm{H}_{2} \mathrm{O}_{2}$ production $(-\triangle-)$; with sorbitol: growth curve $\left(-\mathbf{Q}^{-}\right), \mathrm{H}_{2} \mathrm{O}_{2}$ production (-O-); with lactose: growth curve $(-\square-), \mathrm{H}_{2} \mathrm{O}_{2}$ production (- $\square-$-).

the quantitative determinations were performed only with these strains. Table II summarises the findings with these two strains grown in B-TSB alone or in combination with the substrate(s), B-TSB alone acting as the control. The growth curves and evolution of $\mathrm{H}_{2} \mathrm{O}_{2}$ production by $S$. oralis NCTC 11427 in B-TSB alone, with glucose, and with glucose plus galactose are shown in fig. 2, and fig. 3 shows the growth curve and curve of $\mathrm{H}_{2} \mathrm{O}_{2}$ production for $S$. sanguis NCTC 7863 in B-TSB alone, with sorbitol and with lactose.

After aeration for $3 \mathrm{~h}, \mathrm{H}_{2} \mathrm{O}_{2}$ production by $S$. oralis NCTC 11427 from peptones in B-TSB was $1.32 \mu \mathrm{g} /$
$10^{6}$ cfu. No $\mathrm{H}_{2} \mathrm{O}_{2}$ was detected in cultures containing ribose, fructose or saccharose, and $<1.32 \mu \mathrm{g} / 10^{6} \mathrm{cfu}$ from glucose, galactose, glucose plus galactose, mannitol and xylitol. The $\mathrm{H}_{2} \mathrm{O}_{2}$ concentrations were $>1.32 \mu \mathrm{g} / 10^{6} \mathrm{cfu}$ in cultures containing arabinose, xylose, mannose, sorbose, sorbitol, lactose and saccharin. The rate of $\mathrm{H}_{2} \mathrm{O}_{2}$ excretion, with the exception of cultures with sorbitol, was slower in all these cases than in control cultures, indicating that these substances reduced the rate of production. Although greater amounts of $\mathrm{H}_{2} \mathrm{O}_{2}$ were produced in total, peak production took longer. 
With $S$. sanguis NCTC $7863, \mathrm{H}_{2} \mathrm{O}_{2}$ production in B-TSB alone was $0.31 \mu \mathrm{g} / 10^{6} \mathrm{cfu}$ after aeration for $4.5 \mathrm{~h} . \mathrm{H}_{2} \mathrm{O}_{2}$ was detected only in cultures containing galactose, lactose, sorbitol and saccharin; the accumulation of $\mathrm{H}_{2} \mathrm{O}_{2}$ was greater than in control cultures only when sorbitol was added, whereas cultures with saccharin produced slightly more $\mathrm{H}_{2} \mathrm{O}_{2}$ than did the control medium. All substrates except sorbitol slowed or stopped $\mathrm{H}_{2} \mathrm{O}_{2}$ generation compared with the controls.

\section{Discussion}

Production of $\mathrm{H}_{2} \mathrm{O}_{2}$ by oral streptococci has often been used to distinguish species, ${ }^{5,16,22,23}$ usually by the use of qualitative methods. ${ }^{23,24}$ However, results are not always clear, depending on the culture medium, reagents and method used to read them. TSA-B-P offers some advantages over TSA-o-D, in so far as the reaction develops within minutes and no additional reagents ware required to detect $\mathrm{H}_{2} \mathrm{O}_{2}$. Moreover, the former medium is more sensitive and minimal amounts of $\mathrm{H}_{2} \mathrm{O}_{2}$ are readily detected.

Of the 11 strains analysed, representing four different species that produced $\mathrm{H}_{2} \mathrm{O}_{2}$, only two produced a detectable amount of $\mathrm{H}_{2} \mathrm{O}_{2}$ in broth. This strongly suggests that tests with solid media (TSA-B-P) are more sensitive than those with liquid media, although this advantage is diminished by the fact that the former are unsuited to quantitative studies. In liquid media (B-TSB), a proportion of the $\mathrm{H}_{2} \mathrm{O}_{2}$ is probably inactivated by oxidising organic compounds, ${ }^{19}$ and by $\mathrm{NADH}$-peroxidase further interfering with detection of $\mathrm{H}_{2} \mathrm{O}_{2}$. In solid media, $\mathrm{H}_{2} \mathrm{O}_{2}$ excreted by bacteria immediately oxidises benzidine, a reaction catalysed by the peroxidase incorporated in the medium.

Quantitative studies of the capacity of oral streptococci to produce $\mathrm{H}_{2} \mathrm{O}_{2}$ should be performed with buffered media, to avoid the decrease in $\mathrm{pH}$ caused by the excretion of lactic acid into the medium, since a change in $\mathrm{pH}$ affects the molar extinction coefficient. ${ }^{19,20}$ Furthermore, B-TSB and the substrates used should be sterilised separately to avoid undesirable reactions between aldoses and phosphate groups which can decrease the available concentration of aldose..$^{25}$ Although sterilisation is not required for polyalcohols and saccharin, this step was included in all experiments to standardise the procedure.

Several authors have stated that oral streptococci require glucose, metabolised by means of the glucose oxidase pathway, for $\mathrm{H}_{2} \mathrm{O}_{2}$ production. ${ }^{2,3,13}$ Our work with $S$. sanguis NCTC 7863 and $S$. oralis NCTC 11427 contradicts this assertion; the addition of glucose to the medium inhibited $\mathrm{H}_{2} \mathrm{O}_{2}$ production. With very few exceptions, such as sorbitol for $S$. sanguis NCTC 7863, the addition of substrates to the control medium slowed $\mathrm{H}_{2} \mathrm{O}_{2}$ generation, although the final concentration of $\mathrm{H}_{2} \mathrm{O}_{2}$ in the medium was higher than that in B-TSB alone.
In substrates metabolised by means of the glycolytic pathway, oxidation-reduction is well-balanced, with the subsequent formation of lactate, and only the utilisation of the pentose phosphate pathway would give rise to the reduction equivalents (NADPH) required to reduce oxygen to $\mathrm{H}_{2} \mathrm{O}_{2}$. This would account for the low $\mathrm{H}_{2} \mathrm{O}_{2}$ production by $S$. oralis NCTC 11427 in the presence of glucose $(0.17 \mu \mathrm{g} /$ $\left.10^{6} \mathrm{cfu}\right)$ or galactose $\left(0 \cdot 30 \mu \mathrm{g} / 10^{6} \mathrm{cfu}\right)$.

In contrast, arabinose metabolism gives rise directly to pyruvate. Because of the lack of production of $\mathrm{NADH}$, pyruvate is not metabolised to lactate, thus favouring the pyruvate oxidase pathway ${ }^{26,27}$ for $\mathrm{H}_{2} \mathrm{O}_{2}$ production. This would explain why arabinose is the most highly peroxidogenic substrate $\left(3.02 \mu \mathrm{g} / 10^{6} \mathrm{cfu}\right)$ for $S$. oralis NCTC 11427.

Sorbitol is metabolised by means of the glycolytic pathway, entering as fructose-6-phosphate and generating an extra molecule of NADH; in comparison with other substrates metabolised by the glycolytic pathway this mechanism would produce $\mathrm{H}_{2} \mathrm{O}_{2}$ by means of NADH-oxidase activity. ${ }^{12,28}$

As saccharose and fructose are readily metabolised, amino-acid degradation is completely inhibited. In addition, these substrates may be able to activate NADH-peroxidase, thus destroying $\mathrm{H}_{2} \mathrm{O}_{2}$.

Unmetabolised saccharin remained unaltered, but nonetheless gave rise to a notable increase in $\mathrm{H}_{2} \mathrm{O}_{2}$ production by $S$. oralis NCTC 11427 , and a slight increase by $S$. sanguis NCTC 7863 . These results may have been due to interaction between saccharin and oxidases, causing increased activity of the latter; alternatively, saccharin may have acted as an NADHperoxidase inhibitor. Arabinose and sorbitol were the most strongly peroxidogenic substrates; this raises the possibility that arabinose and sorbitol may have advantages as saccharose substitutes.

One can postulate that $\mathrm{H}_{2} \mathrm{O}_{2}$ production may be a selective factor in the different habitats of the oral cavity, whereby bacteria producing $\mathrm{H}_{2} \mathrm{O}_{2}$ are favoured in the competition for colonisation. In this study, two species of oral streptococci excreted high levels of $\mathrm{H}_{2} \mathrm{O}_{2}$ into the medium; in quantitative terms, this feature appears to be strain-dependent. Although $S$. sanguis NCTC 7863 and S. oralis NCTC 11427 were peroxidogenic in both solid and liquid media, $S$. sanguis JENA 2697, S. mitis OGS 218 and others produced detectable amounts of $\mathrm{H}_{2} \mathrm{O}_{2}$ only in solid media, which are more sensitive indicators of $\mathrm{H}_{2} \mathrm{O}_{2}$ than liquid media. These findings are of potential importance for studies of peroxide production in vivo.

In conclusion, $\mathrm{H}_{2} \mathrm{O}_{2}$ production by oral streptococci appears to be species- and strain-dependent, and varies according to the substrate used. The accurate detection of $\mathrm{H}_{2} \mathrm{O}_{2}$ in vitro depends on the method used, regardless of whether solid or liquid media are used, although the former are more sensitive. 
This study was supported partly by the Education Council of the Andalusian Regional Government through a project titled "Microbiology, immunology and epidemiology of oral diseases". We thank

\section{References}

1. Holmberg K, Hallander HO. Production of bactericidal concentrations of hydrogen peroxide by Streptococcus sanguis. Arch Oral Biol 1973; 18: 423-434.

2. LeBien TW, Bromel MC. Antibacterial properties of a peroxidogenic strain of Streptococcus mitior (mitis). Can J Microbiol 1975; 21: 101-103.

3. Vernazza TR, Melville TH. Inhibitory activity of Streptococcus mitis against oral bacteria. Microbios 1979; 26 : 95-101.

4. Willcox MDP, Drucker DB. Partial characterisation of the inhibitory substances produced by Streptococcus oralis and related species. Microbios $1988 ; \mathbf{5 5}: 135-145$.

5. McLeod JW, Gordon J. Production of hydrogen peroxide by bacteria. Biochem J 1922; 16: 499-504.

6. Thompson R, Johnson A. The inhibitory action of saliva on the diphtheria bacillus: hydrogen peroxide, the inhibitory agent produced by salivary streptococci. J Infect Dis 1951 ; 88: $81-85$.

7. Hamon CB, Klebanoff SJ. A peroxidase-mediated, Streptococcus mitis-dependent antimicrobial system in saliva. $J$ Exp Med 1973; 137: 438-450.

8. Fridovich I. Superoxide dismutases. Annu Rev Biochem 1975; 44: $147-159$.

9. Dingman DW, Stalhy DP. Protection of Bacillus larvae from oxygen toxicity with emphasis on the role of catalase. Appl Environ Microbiol 1984; 47: 1228-1237.

10. Edwardsson S. Microorganimos asociados a la caries dental. In: Thylstrup A, Fejerskov O (eds) Caries. Barcelona, Ediciones Doyma. 1988: 85.

11. Cole JA. A biochemical approach to the control of dental caries. Biochem Soc Trans 1977; 5: 1232-1239.

12. Dolin MI. Cytochrome-independent electron transport enzymes of bacteria. In: Gunsalus IC, Stanier RY (eds) The bacteria, vol 2. New York, Academic Press. 1961: 425.

13. Thomas EL, Pera KA. Oxygen metabolism of Streptococcus mutans: uptake of oxygen and release of superoxide and hydrogen peroxide. J Bacteriol 1983; 154: 1236-1244.

14. DiGuiseppi J, Fridovich I. Oxygen toxicity in Streptococcus sanguis. The relative importance of superoxide and hydroxyl radicals. J Biol Chem 1982; 257: 4046-4051.
Dr M. Hayes of the Department of Biochemistry, Medical School, University of Bristol, for providing reference strains and valuable suggestions regarding the study.

15. Dolin MI. The DPNH-oxidizing enzymes of Streptococcus faecalis. II. The enzymes utilizing oxygen, cytochrome c, peroxide and 2,6-dichlorophenol-indophenol or ferricyanide as oxidants. Arch Biochem Biophys 1955; 55: 415-435.

16. Hardie JM. Oral streptococci. In: Sneath PHA, Mair NS, Sharpe ME, Holt JG (eds) Bergey's Manual of systematic bacteriology, 9th ed, vol 2. Baltimore, Williams and Wilkins Co. 1986: 1054-1063.

17. Loesche WJ. Role of Streptococcus mutans in human dental decay. Microbiol Rev 1986; 50: 353-380.

18. García-Villanova $R$ (ed). Volumetrías de óxido-reducción. In: Análisis químico. Principios y métodos, 2nd edn. Granada, Universidad de Granada. 1980: 347.

19. Lehninger AL. Enzimas de oxido-reducción y transporte electrónico. In: Lehninger AL (ed) Bioquímica, 2nd edn. Barcelona, Ediciones Omega. 1978: 487.

20. Levine IN (ed). Espectroscopía y fotoquímica. In: Physicochemistry. Bogotá, McGraw Hill. 1981: 472.

21. Calvo F (ed). Estadística aplicada. Bilbao, Deusto. 1978: 596.

22. Hamada S, Slade HD. Biology, immunology, and cariogenicity of Streptococcus mutans. Microbiol Rev 1980; 44: 331-384.

23. Whiley RA, Fraser H, Hardie JM, Beighton D. Phenotypic differentiation of Streptococcus intermedius, Streptococcus constellatus, and Streptococcus anginosus strain within the "Streptococcus milleri Group". J Clin Microbiol 1990; 28: 1497-1501.

24. Whittenbury R. Hydrogen peroxide formation and catalase activity in lactic acid bacteria. J Gen Microbiol 1964; 35 : $13-26$.

25. Carlsson J, Iwami Y, Yamada T. Hydrogen peroxide excretion by oral streptococci and effect of lactoperoxidasethiocyanate-hydrogen peroxide. Infect Immun 1983; 40: $70-80$.

26. Thylstrup A, Fejerskov O (eds). Actividades metabólicas de las bacterias de la cavidad oral. In: Caries. Barcelona, Ediciones Doyma. 1988: 56.

27. Carlsson J, Edlund M-BK, Lundmark SKE. Characteristics of a hydrogen peroxide-forming pyruvate oxidase from Streptococcus sanguis. Oral Microbiol Immunol 1987; 2: $15-20$.

28. Low IE, Zimkus SM. Reduced nicotinamide adenine dinucleotide oxidase and $\mathrm{H}_{2} \mathrm{O}_{2}$ formation of Mycoplasma pneumoniae. J Bacteriol 1973; 116: 346-354. 